\title{
Melanin-concentrating hormone receptors (version 2019.4) in the IUPHAR/BPS Guide to Pharmacology Database
}

\author{
Valérie Audinot ${ }^{1}$, Jean A. Boutin², Bernard Lakaye ${ }^{3}$, Jean-Louis Nahon ${ }^{4}$ and Yumito Saito ${ }^{5}$ \\ 1. Institut de recherches Servier, France \\ 2. Institut de Recherches Internationales Servier, France \\ 3. University of Liège, Belgium \\ 4. CNRS Sophia Antipolis, France \\ 5. Hiroshima University, Japan
}

\begin{abstract}
Melanin-concentrating hormone $(\mathrm{MCH})$ receptors (provisional nomenclature as recommended by $\mathbf{N C}$ IUPHAR [31]) are activated by an endogenous nonadecameric cyclic peptide identical in humans and rats (DFDMLRCMLGRVYRPCWQV; mammalian MCH) generated from a precursor (PMCH, P20382), which also produces neuropeptide El and neuropeptide GE.
\end{abstract}

\section{Contents}

This is a citation summary for Melanin-concentrating hormone receptors in the Guide to Pharmacology database (GtoPdb). It exists purely as an adjunct to the database to facilitate the recognition of citations to and from the database by citation analyzers. Readers will almost certainly want to visit the relevant sections of the database which are given here under database links.

GtoPdb is an expert-driven guide to pharmacological targets and the substances that act on them. GtoPdb is a reference work which is most usefully represented as an on-line database. As in any publication this work should be appropriately cited, and the papers it cites should also be recognized. This document provides a citation for the relevant parts of the database, and also provides a reference list for the research cited by those parts.

Please note that the database version for the citations given in GtoPdb are to the most recent preceding version in which the family or its subfamilies and targets were substantially changed. The links below are to the current version. If you need to consult the cited version, rather than the most recent version, please contact the GtoPdb curators.

\section{Database links}

Melanin-concentrating hormone receptors

http://www.guidetopharmacology.org/GRAC/FamilyDisplayForward?familyld=37

Introduction to Melanin-concentrating hormone receptors

http://www.guidetopharmacology.org/GRAC/FamilylntroductionForward?familyld=37

Receptors 
$\mathrm{MCH}_{1}$ receptor

http://www.guidetopharmacology.org/GRAC/ObjectDisplayForward?objectld=280

$\mathrm{MCH}_{2}$ receptor

http://www.guidetopharmacology.org/GRAC/ObjectDisplayForward?objectld=281

\section{References}

1. Adamantidis A, Salvert D, Goutagny R, Lakaye B, Gervasoni D, Grisar T, Luppi PH and Fort P. (2008) Sleep architecture of the melanin-concentrating hormone receptor 1-knockout mice. Eur. J. Neurosci. 27: 1793-800 [PMID:18380672]

2. Adamantidis A, Thomas E, Foidart A, Tyhon A, Coumans B, Minet A, Tirelli E, Seutin V, Grisar T and Lakaye B. (2005) Disrupting the melanin-concentrating hormone receptor 1 in mice leads to cognitive deficits and alterations of NMDA receptor function. Eur. J. Neurosci. 21: 2837-44 [PMID:15926931]

3. Adams AC, Domouzoglou EM, Chee MJ, Segal-Lieberman G, Pissios P and Maratos-Flier E. (2011) Ablation of the hypothalamic neuropeptide melanin concentrating hormone is associated with behavioral abnormalities that reflect impaired olfactory integration. Behav. Brain Res. 224: 195-200 [PMID:21669232]

4. Ahnaou A, Dautzenberg FM, Huysmans H, Steckler T and Drinkenburg WH. (2011) Contribution of melanin-concentrating hormone $(\mathrm{MCH} 1)$ receptor to thermoregulation and sleep stabilization: evidence from MCH1 (-/-) mice. Behav. Brain Res. 218: $42-50$ [PMID:21074567]

5. An S, Cutler G, Zhao JJ, Huang SG, Tian H, Li W, Liang L, Rich M, Bakleh A and Du tet al.. (2001) Identification and characterization of a melanin-concentrating hormone receptor. Proc. Natl. Acad. Sci. U.S.A. 98: 7576-81 [PMID:11416225]

6. AstraZeneca. AZ13483342.

7. Audinot V, Beauverger P, Lahaye C, Suply T, Rodriguez M, Ouvry C, Lamamy V, Imbert J, Rique H and Nahon JL et al.. (2001) Structure-activity relationship studies of melanin-concentrating hormone (MCH)related peptide ligands at SLC-1, the human MCH receptor. J. Biol. Chem. 276: 13554-62 [PMID:11278733]

8. Audinot V, Lahaye $C$, Suply $T$, Beauverger $P$, Rodriguez M, Galizzi JP, Fauchère JL and Boutin JA. (2001) [125I]-S36057: a new and highly potent radioligand for the melanin-concentrating hormone receptor. Br. J. Pharmacol. 133: 371-8 [PMID:11375253]

9. Audinot V, Zuana OD, Fabry N, Ouvry C, Nosjean O, Henlin JM, Fauchère JL and Boutin JA. (2009) S38151 [p-guanidinobenzoyl-[Des-Gly(10)]-MCH(7-17)] is a potent and selective antagonist at the $\mathrm{MCH}(1)$ receptor and has anti-feeding properties in vivo. Peptides 30: 1997-2007 [PMID:19619599]

10. Aughton KL, Hamilton-Smith K, Gupta J, Morton JS, Wayman CP and Jackson VM. (2008) Pharmacological profiling of neuropeptides on rabbit vaginal wall and vaginal artery smooth muscle in vitro. Br. J. Pharmacol. 155: 236-43 [PMID:18587425]

11. Bednarek MA, Hreniuk DL, Tan C, Palyha OC, MacNeil DJ, Van der Ploeg LH, Howard AD and Feighner SD. (2002) Synthesis and biological evaluation in vitro of selective, high affinity peptide antagonists of human melanin-concentrating hormone action at human melanin-concentrating hormone receptor 1. Biochemistry 41: 6383-90 [PMID:12009900]

12. Bednarek MA, Tan C, Hreniuk DL, Palyha OC, MacNeil DJ, Van Der Ploeg LH, Howard AD and Feighner SD. (2002) Synthesis and biological evaluation in vitro of a selective, high potency peptide agonist of human melanin-concentrating hormone action at human melanin-concentrating hormone receptor $1 . \mathrm{J}$. Biol. Chem. 277: 13821-6 [PMID:11839762]

13. Benedetto L, Rodriguez-Servetti Z, Lagos P, D'Almeida V, Monti JM and Torterolo P. (2013) Microinjection of melanin concentrating hormone into the lateral preoptic area promotes non-REM sleep in the rat.

Peptides 39: 11-5 [PMID:23123302]

14. Berbari NF, Johnson AD, Lewis JS, Askwith CC and Mykytyn K. (2008) Identification of ciliary localization sequences within the third intracellular loop of $G$ protein-coupled receptors. Mol. Biol. Cell 19: 1540-7 [PMID:18256283]

15. Borowsky B, Durkin MM, Ogozalek K, Marzabadi MR, DeLeon J, Lagu B, Heurich R, Lichtblau H, 
Shaposhnik Z, Daniewska I, Blackburn TP, Branchek TA, Gerald C, Vaysse PJ and Forray C. (2002) Antidepressant, anxiolytic and anorectic effects of a melanin-concentrating hormone-1 receptor antagonist. Nat Med 8: 825-830 [PMID:12118247]

16. Burgaud JL, Poosti R, Fehrentz JA, Martinez J and Nahon JL. (1997) Melanin-concentrating hormone binding sites in human SVK14 keratinocytes. Biochem. Biophys. Res. Commun. 241: 622-9 [PMID:9434758]

17. Bächner D, Kreienkamp H, Weise C, Buck F and Richter D. (1999) Identification of melanin concentrating hormone $(\mathrm{MCH})$ as the natural ligand for the orphan somatostatin-like receptor 1 (SLC-1). FEBS Lett. 457: 522-4 [PMID:10471841]

18. Bächner D, Kreienkamp HJ and Richter D. (2002) MIZIP, a highly conserved, vertebrate specific melaninconcentrating hormone receptor 1 interacting zinc-finger protein. FEBS Lett. 526: 124-8 [PMID:12208518]

19. Chaki S, Funakoshi T, Hirota-Okuno S, Nishiguchi M, Shimazaki T, lijima M, Grottick AJ, Kanuma K, Omodera K, Sekiguchi Y, Okuyama S, Tran TA, Semple G and Thomsen W. (2005) Anxiolytic- and antidepressant-like profile of ATC0065 and ATC0175: nonpeptidic and orally active melanin-concentrating hormone receptor 1 antagonists. J Pharmacol Exp Ther 313: 831-839 [PMID:15677346]

20. Chambers J, Ames RS, Bergsma D, Muir A, Fitzgerald LR, Hervieu G, Dytko GM, Foley JJ, Martin J and Liu WS et al.. (1999) Melanin-concentrating hormone is the cognate ligand for the orphan G-proteincoupled receptor SLC-1. Nature 400: 261-5 [PMID:10421367]

21. Chen X, Mihalic J, Fan P, Liang L, Lindstrom M, Wong S, Ye Q, Fu Y, Jaen J and Chen JLet al.. (2012) Discovery and characterization of a potent and selective antagonist of melanin-concentrating hormone receptor 2. Bioorg. Med. Chem. Lett. 22: 363-6 [PMID:22123324]

22. Chen Y, Hu C, Hsu CK, Zhang Q, Bi C, Asnicar M, Hsiung HM, Fox N, Slieker LJ and Yang Dœet al.. (2002) Targeted disruption of the melanin-concentrating hormone receptor-1 results in hyperphagia and resistance to diet-induced obesity. Endocrinology 143: 2469-77 [PMID:12072376]

23. Chung S, Hopf FW, Nagasaki H, Li CY, Belluzzi JD, Bonci A and Civelli O. (2009) The melaninconcentrating hormone system modulates cocaine reward. Proc. Natl. Acad. Sci. U.S.A. 106: 6772-7 [PMID:19342492]

24. Chung S, Liao XH, Di Cosmo C, Van Sande J, Wang Z, Refetoff S and Civelli O. (2012) Disruption of the melanin-concentrating hormone receptor 1 (MCH1R) affects thyroid function. Endocrinology 153: 6145-54 [PMID:23024261]

25. Cippitelli A, Karlsson C, Shaw JL, Thorsell A, Gehlert DR and Heilig M. (2010) Suppression of alcohol selfadministration and reinstatement of alcohol seeking by melanin-concentrating hormone receptor $1(\mathrm{MCH} 1$ R) antagonism in Wistar rats. Psychopharmacology (Berl.) 211: 367-75 [PMID:20628734]

26. Conductier G, Brau F, Viola A, Langlet F, Ramkumar N, Dehouck B, Lemaire T, Chapot R, Lucas L and Rovère $C$ et al.. (2013) Melanin-concentrating hormone regulates beat frequency of ependymal cilia and ventricular volume. Nat. Neurosci. 16: 845-7 [PMID:23708141]

27. Conductier G, Martin AO, Risold PY, Jego S, Lavoie R, Lafont C, Mollard P, Adamantidis A and Nahon JL. (2013) Control of ventricular ciliary beating by the melanin concentrating hormone-expressing neurons of the lateral hypothalamus: a functional imaging survey. Front Endocrinol (Lausanne) 4: 182 [PMID:24324458]

28. Cotta-Grand N, Rovère C, Guyon A, Cervantes A, Brau F and Nahon JL. (2009) Melanin-concentrating hormone induces neurite outgrowth in human neuroblastoma SH-SY5Y cells through p53 and MAPKinase signaling pathways. Peptides 30: 2014-24 [PMID:19540893]

29. David DJ, Klemenhagen KC, Holick KA, Saxe MD, Mendez I, Santarelli L, Craig D, Zong H, Swanson C, Hegde LG, Ping XI, Dong D, Marzabadi MR, Gerald C and Hen R. (2007) Efficacy of the MCHR1 antagonist N-[3-(1-\{[4-(3,4-difluorophenoxy)phenyl]methyl\}(4-piperidyl))-4-methylphenyl]-2methylpropanamide (SNAP 94847) in mouse models of anxiety and depression following acute and chronic administration is independent of hippocampal neurogenesis. $J$ Pharmacol Exp Ther[PMID:17237257]

30. Duncan EA, Rider TR, Jandacek RJ, Clegg DJ, Benoit SC, Tso P and Woods SC. (2006) The regulation of 
alcohol intake by melanin-concentrating hormone in rats. Pharmacol. Biochem. Behav. 85: 728-35 [PMID:17188345]

31. Foord SM, Bonner TI, Neubig RR, Rosser EM, Pin JP, Davenport AP, Spedding M and Harmar AJ. (2005) International Union of Pharmacology. XLVI. G protein-coupled receptor list. Pharmacol. Rev. 57: 279-88 [PMID:15914470]

32. Fox BM, Natero R, Richard K, Connors R, Roveto PM, Beckmann H, Haller K, Golde J, Xiao SH and Kayser F. (2011) Novel pyrrolidine melanin-concentrating hormone receptor 1 antagonists with reduced hERG inhibition. Bioorg. Med. Chem. Lett. 21: 2460-7 [PMID:21414780]

33. Francke F, Ward RJ, Jenkins L, Kellett E, Richter D, Milligan G and Bächner D. (2006) Interaction of neurochondrin with the melanin-concentrating hormone receptor 1 interferes with $\mathrm{G}$ protein-coupled signal transduction but not agonist-mediated internalization. J. Biol. Chem. 281: 32496-507 [PMID:16945926]

34. Frezzotti R and Caporossi A. (1990) Pathogenesis of posterior capsular opacification. Part I. Epidemiological and clinico-statistical data. J Cataract Refract Surg 16: 347-52 [PMID:2355323]

35. Gehlert DR, Rasmussen K, Shaw J, Li X, Ardayfio P, Craft L, Coskun T, Zhang HY, Chen Y and Witkin JM. (2009) Preclinical evaluation of melanin-concentrating hormone receptor 1 antagonism for the treatment of obesity and depression. J. Pharmacol. Exp. Ther. 329: 429-38 [PMID:19182070]

36. Georgescu D, Sears RM, Hommel JD, Barrot M, Bolaños CA, Marsh DJ, Bednarek MA, Bibb JA, MaratosFlier E and Nestler EJ et al.. (2005) The hypothalamic neuropeptide melanin-concentrating hormone acts in the nucleus accumbens to modulate feeding behavior and forced-swim performance. J. Neurosci. 25: 2933-40 [PMID:15772353]

37. Geuzaine A, Tyhon A, Grisar T, Brabant C, Lakaye B and Tirelli E. (2014) Amphetamine reward in food restricted mice lacking the melanin-concentrating hormone receptor-1. Behav. Brain Res. 262: 14-20 [PMID:24412349]

38. Giordanetto F, Karlsson O, Lindberg J, Larsson LO, Linusson A, Evertsson E, Morgan DG and Inghardt T. (2007) Discovery of cyclopentane- and cyclohexane-trans-1,3-diamines as potent melanin-concentrating hormone receptor 1 antagonists. Bioorg. Med. Chem. Lett. 17: 4232-41 [PMID:17532215]

39. Guo T, Gu H, Hobbs DW, Busler DE and Rokosz LL. (2007) Discovery of tetralin ureas as potent melanin concentrating hormone 1 receptor antagonists. Bioorg. Med. Chem. Lett. 17: 1718-21 [PMID:17251014]

40. Hamamoto A, Mizusawa K, Takahashi A and Saito Y. (2011) Signalling pathway of goldfish melaninconcentrating hormone receptors 1 and 2. Regul. Pept. 169: 6-12 [PMID:21539863]

41. Hawes BE, Kil E, Green B, O'Neill K, Fried S and Graziano MP. (2000) The melanin-concentrating hormone receptor couples to multiple $G$ proteins to activate diverse intracellular signaling pathways. Endocrinology 141: 4524-32 [PMID:11108264]

42. Hertzog DL, Al-Barazanji KA, Bigham EC, Bishop MJ, Britt CS, Carlton DL, Cooper JP, Daniels AJ, Garrido DM and Goetz AS et al.. (2006) The discovery and optimization of pyrimidinone-containing MCH R1 antagonists. Bioorg. Med. Chem. Lett. 16: 4723-7 [PMID:16870432]

43. Hervieu G, Volant K, Grishina O, Descroix-Vagne M and Nahon JL. (1996) Similarities in cellular expression and functions of melanin-concentrating hormone and atrial natriuretic factor in the rat digestive tract. Endocrinology 137: 561-71 [PMID:8593803]

44. Hervieu GJ, Cluderay JE, Harrison D, Meakin J, Maycox P, Nasir S and Leslie RA. (2000) The distribution of the mRNA and protein products of the melanin-concentrating hormone $(\mathrm{MCH})$ receptor gene, slc-1, in the central nervous system of the rat. Eur. J. Neurosci. 12: 1194-216 [PMID:10762350]

45. Hill J, Duckworth M, Murdock P, Rennie G, Sabido-David C, Ames RS, Szekeres P, Wilson S, Bergsma DJ and Gloger IS et al.. (2001) Molecular cloning and functional characterization of $\mathrm{MCH} 2$, a novel human MCH receptor. J. Biol. Chem. 276: 20125-9 [PMID:11274220]

46. Jego S, Glasgow SD, Herrera CG, Ekstrand M, Reed SJ, Boyce R, Friedman J, Burdakov D and Adamantidis AR. (2013) Optogenetic identification of a rapid eye movement sleep modulatory circuit in the hypothalamus. Nat. Neurosci. 16: 1637-43 [PMID:24056699]

47. Karagiannis AK, Ziogas DC, Gras-Miralles B, Geiger BM, Nagel J, Trebicka E, Najarian R, Cherayil BJ and Kokkotou E. (2013) Increased susceptibility of melanin-concentrating hormone-deficient mice to infection 
with Salmonella enterica serovar Typhimurium. Infect. Immun. 81: 166-72 [PMID:23115043]

48. Kasai S, Kamata M, Masada S, Kunitomo J, Kamaura M, Okawa T, Takami K, Ogino H, Nakano Y and Ashina S et al.. (2012) Synthesis, structure-activity relationship, and pharmacological studies of novel melanin-concentrating hormone receptor 1 antagonists 3-aminomethylquinolines: reducing human ether-ago-go-related gene (hERG) associated liabilities. J. Med. Chem. 55: 4336-51 [PMID:22490048]

49. Kawauchi H, Kawazoe I, Tsubokawa M, Kishida M and Baker BI. (1983) Characterization of melaninconcentrating hormone in chum salmon pituitaries. Nature 305: 321-3 [PMID:6621686]

50. Kobayashi Y, Hamamoto A, Hirayama T and Saito Y. (2015) Molecular cloning, expression, and signaling pathway of four melanin-concentrating hormone receptors from Xenopus tropicalis. Gen. Comp.

Endocrinol. 212: 114-23 [PMID:24662390]

51. Kokkotou E, Espinoza DO, Torres D, Karagiannides I, Kosteletos S, Savidge T, O'Brien M and Pothoulakis C. (2009) Melanin-concentrating hormone $(\mathrm{MCH})$ modulates $\mathrm{C}$ difficile toxin A-mediated enteritis in mice. Gut 58: 34-40 [PMID:18824554]

52. Kokkotou EG, Tritos NA, Mastaitis JW, Slieker L and Maratos-Flier E. (2001) Melanin-concentrating hormone receptor is a target of leptin action in the mouse brain. Endocrinology 142: 680-6 [PMID:11159839]

53. Kolakowski Jr LF, Jung BP, Nguyen T, Johnson MP, Lynch KR, Cheng R, Heng HH, George SR and O'Dowd BF. (1996) Characterization of a human gene related to genes encoding somatostatin receptors. FEBS Lett. 398: 253-8 [PMID:8977118]

54. Konadhode RR, Pelluru D, Blanco-Centurion C, Zayachkivsky A, Liu M, Unde T, Glen Jr WB, van den Pol AN, Mulholland PJ and Shiromani PJ. (2013) Optogenetic stimulation of MCH neurons increases sleep. J. Neurosci. 33: 10257-63 [PMID:23785141]

55. Kowalski TJ, Farley C, Cohen-Williams ME, Varty G and Spar BD. (2004) Melanin-concentrating hormone1 receptor antagonism decreases feeding by reducing meal size. Eur. J. Pharmacol. 497: 41-7 [PMID:15321733]

56. Lagos $\mathrm{P}$, Monti JM, Jantos $\mathrm{H}$ and Torterolo P. (2012) Microinjection of the melanin-concentrating hormone into the lateral basal forebrain increases REM sleep and reduces wakefulness in the rat. Life Sci. 90: 8959 [PMID:22579511]

57. Lagos $P$, Torterolo P, Jantos H, Chase MH and Monti JM. (2009) Effects on sleep of melaninconcentrating hormone $(\mathrm{MCH})$ microinjections into the dorsal raphe nucleus. Brain Res. 1265: 103-10 [PMID:19230831]

58. Lakaye B, Minet A, Zorzi W and Grisar T. (1998) Cloning of the rat brain cDNA encoding for the SLC-1 G protein-coupled receptor reveals the presence of an intron in the gene. Biochim Biophys Acta 1401: 216220 [PMID:9531978]

59. Lalonde R and Qian S. (2007) Exploratory activity, motor coordination, and spatial learning in Mchr1 knockout mice. Behav Brain Res 178: 293-304 [PMID:17270288]

60. Lembo PM, Grazzini E, Cao J, Hubatsch DA, Pelletier M, Hoffert C, St-Onge S, Pou C, Labrecque J and Groblewski T et al.. (1999) The receptor for the orexigenic peptide melanin-concentrating hormone is a Gprotein-coupled receptor. Nat. Cell Biol. 1: 267-71 [PMID:10559938]

61. Lim CJ, Kim SH, Lee BH, Oh KS and Yi KY. (2012) 4-arylphthalazin-1(2H)-one derivatives as potent antagonists of the melanin concentrating hormone receptor 1 (MCH-R1). Bioorg. Med. Chem. Lett. 22: 427-30 [PMID:22137790]

62. Logan DW, Bryson-Richardson RJ, Pagán KE, Taylor MS, Currie PD and Jackson IJ. (2003) The structure and evolution of the melanocortin and $\mathrm{MCH}$ receptors in fish and mammals. Genomics 81: 184-91 [PMID:12620396]

63. Lynch JK, Freeman JC, Judd AS, lyengar R, Mulhern M, Zhao G, Napier JJ, Wodka D, Brodjian S and Dayton BD et al.. (2006) Optimization of chromone-2-carboxamide melanin concentrating hormone receptor 1 antagonists: assessment of potency, efficacy, and cardiovascular safety. J. Med. Chem. 49: 6569-84 [PMID:17064075]

64. Marsh DJ, Weingarth DT, Novi DE, Chen HY, Trumbauer ME, Chen AS, Guan XM, Jiang MM, Feng Y and 
Camacho RE et al.. (2002) Melanin-concentrating hormone 1 receptor-deficient mice are lean, hyperactive, and hyperphagic and have altered metabolism. Proc. Natl. Acad. Sci. U.S.A. 99: 3240-5 [PMID:11867747]

65. McBriar MD. (2006) Recent advances in the discovery of melanin-concentrating hormone receptor antagonists. Curr Opin Drug Discov Deve/ 9: 496-508 [PMID:16889232]

66. Millan MJ, Gobert A, Panayi F, Rivet JM, Dekeyne A, Brocco M, Ortuno JC and Di Cara B. (2008) The melanin-concentrating hormone1 receptor antagonists, SNAP-7941 and GW3430, enhance social recognition and dialysate levels of acetylcholine in the frontal cortex of rats. Int. J. Neuropsychopharmacol. 11: 1105-1122 [PMID:18466669]

67. Miyamoto-Matsubara M, Chung $S$ and Saito Y. (2010) Functional interaction of regulator of G protein signaling-2 with melanin-concentrating hormone receptor 1. Ann. N. Y. Acad. Sci. 1200: 112-9 [PMID:20633139]

68. Miyamoto-Matsubara M, Saitoh O, Maruyama K, Aizaki Y and Saito Y. (2008) Regulation of melaninconcentrating hormone receptor 1 signaling by RGS 8 with the receptor third intracellular loop. Cell. Signal. 20: 2084-94 [PMID:18760349]

69. Miyoshi K, Kasahara K, Miyazaki I and Asanuma M. (2009) Lithium treatment elongates primary cilia in the mouse brain and in cultured cells. Biochem. Biophys. Res. Commun. 388: 757-62 [PMID:19703416]

70. Mizusawa K, Amiya N, Yamaguchi Y, Takabe S, Amano M, Breves JP, Fox BK, Grau EG, Hyodo S and Takahashi A. (2012) Identification of mRNAs coding for mammalian-type melanin-concentrating hormone and its receptors in the scalloped hammerhead shark Sphyrna lewini. Gen. Comp. Endocrinol. 179: 78-87 [PMID:22884735]

71. Mizusawa K, Saito Y, Wang Z, Kobayashi Y, Matsuda K and Takahashi A. (2009) Molecular cloning and expression of two melanin-concentrating hormone receptors in goldfish. Peptides 30: 1990-6 [PMID:19397943]

72. Morganstern I, Chang GQ, Chen YW, Barson JR, Zhiyu Y, Hoebel BG and Leibowitz SF. (2010) Role of melanin-concentrating hormone in the control of ethanol consumption: Region-specific effects revealed by expression and injection studies. Physiol. Behav. 101: 428-37 [PMID:20670637]

73. Mori M, Harada M, Terao Y, Sugo T, Watanabe T, Shimomura Y, Abe M, Shintani Y, Onda H and Nishimura $O$ et al.. (2001) Cloning of a novel G protein-coupled receptor, SLT, a subtype of the melaninconcentrating hormone receptor. Biochem. Biophys. Res. Commun. 283: 1013-8 [PMID:11355873]

74. Murdoch H, Feng GJ, Bächner D, Ormiston L, White JH, Richter D and Milligan G. (2005) Periplakin interferes with $G$ protein activation by the melanin-concentrating hormone receptor- 1 by binding to the proximal segment of the receptor C-terminal tail. J. Biol. Chem. 280: 8208-20 [PMID:15590649]

75. Méndez-Andino JL and Wos JA. (2007) MCH-R1 antagonists: what is keeping most research programs away from the clinic? Drug Discov. Today 12: 972-9 [PMID:17993417]

76. Nagasaki H, Chung S, Dooley CT, Wang Z, Li C, Saito Y, Clark SD, Houghten RA and Civelli O. (2009) The pharmacological properties of a novel $\mathrm{MCH} 1$ receptor antagonist isolated from combinatorial libraries. Eur. J. Pharmacol. 602: 194-202 [PMID:19041642]

77. Nagel JM, Geiger BM, Karagiannis AK, Gras-Miralles B, Horst D, Najarian RM, Ziogas DC, Chen X and Kokkotou E. (2012) Reduced intestinal tumorigenesis in APCmin mice lacking melanin-concentrating hormone. PLoS ONE 7: e41914 [PMID:22848656]

78. Nahon JL, Presse F, Bittencourt JC, Sawchenko PE and Vale W. (1989) The rat melanin-concentrating hormone messenger ribonucleic acid encodes multiple putative neuropeptides coexpressed in the dorsolateral hypothalamus. Endocrinology 125: 2056-65 [PMID:2477226]

79. Pachoud B, Adamantidis A, Ravassard P, Luppi PH, Grisar T, Lakaye B and Salin PA. (2010) Major impairments of glutamatergic transmission and long-term synaptic plasticity in the hippocampus of mice lacking the melanin-concentrating hormone receptor-1. J. Neurophysiol. 104: 1417-25 [PMID:20592115]

80. Pissios P, Bradley RL and Maratos-Flier E. (2006) Expanding the scales: The multiple roles of MCH in regulating energy balance and other biological functions. Endocr. Rev. 27: 606-20 [PMID:16788162]

81. Pissios P, Ozcan U, Kokkotou E, Okada T, Liew CW, Liu S, Peters JN, Dahlgren G, Karamchandani J and Kudva YC et al.. (2007) Melanin concentrating hormone is a novel regulator of islet function and growth. 
Diabetes 56: 311-9 [PMID:17259374]

82. Pissios P, Trombly DJ, Tzameli I and Maratos-Flier E. (2003) Melanin-concentrating hormone receptor 1 activates extracellular signal-regulated kinase and synergizes with $\mathrm{G}(\mathrm{s})$-coupled pathways. Endocrinology 144: 3514-23 [PMID:12865333]

83. Presse F, Nahon JL, Fischer WH and Vale W. (1990) Structure of the human melanin concentrating hormone mRNA. Mol. Endocrinol. 4: 632-7 [PMID:2149166]

84. Qu D, Ludwig DS, Gammeltoft S, Piper M, Pelleymounter MA, Cullen MJ, Mathes WF, Przypek R, Kanarek $R$ and Maratos-Flier E. (1996) A role for melanin-concentrating hormone in the central regulation of feeding behaviour. Nature 380: 243-7 [PMID:8637571]

85. Rivera G, Bocanegra-García V, Galiano S, Cirauqui N, Ceras J, Pérez S, Aldana I and Monge A. (2008) Melanin-concentrating hormone receptor 1 antagonists: a new perspective for the pharmacologic treatment of obesity. Curr. Med. Chem. 15: 1025-43 [PMID:18393860]

86. Rodriguez M, Beauverger P, Naime I, Rique H, Ouvry C, Souchaud S, Dromaint S, Nagel N, Suply T and Audinot $V$ et al.. (2001) Cloning and molecular characterization of the novel human melanin-concentrating hormone receptor MCH2. Mol. Pharmacol. 60: 632-9 [PMID:11562423]

87. Rossi M, Choi SJ, O'Shea D, Miyoshi T, Ghatei MA and Bloom SR. (1997) Melanin-concentrating hormone acutely stimulates feeding, but chronic administration has no effect on body weight. Endocrinology 138: 351-5 [PMID:8977423]

88. Sailer AW, Sano H, Zeng Z, McDonald TP, Pan J, Pong SS, Feighner SD, Tan CP, Fukami T and Iwaasa $\mathrm{H}$ et al.. (2001) Identification and characterization of a second melanin-concentrating hormone receptor, MCH-2R. Proc. Natl. Acad. Sci. U.S.A. 98: 7564-9 [PMID:11404457]

89. Saito $Y$, Cheng M, Leslie FM and Civelli O. (2001) Expression of the melanin-concentrating hormone (MCH) receptor mRNA in the rat brain. J. Comp. Neurol. 435: 26-40 [PMID:11370009]

90. Saito $Y$ and Nagasaki H. (2008) The melanin-concentrating hormone system and its physiological functions. Results Probl Cell Differ 46: 159-79 [PMID:18227983]

91. Saito Y, Nothacker HP and Civelli O. (2000) Melanin-concentrating hormone receptor: an orphan receptor fits the key. Trends Endocrinol. Metab. 11: 299-303 [PMID:10996523]

92. Saito Y, Nothacker HP, Wang Z, Lin SH, Leslie F and Civelli O. (1999) Molecular characterization of the melanin-concentrating-hormone receptor. Nature 400: 265-9 [PMID:10421368]

93. Saito Y, Wang Z, Hagino-Yamagishi K, Civelli O, Kawashima S and Maruyama K. (2001) Endogenous melanin-concentrating hormone receptor SLC-1 in human melanoma SK-MEL-37 cells. Biochem. Biophys. Res. Commun. 289: 44-50 [PMID:11708774]

94. Sakurai T, Ogawa K, Ishihara $Y$, Kasai S and Nakayama M. (2014) The MCH(1) receptor, an anti-obesity target, is allosterically inhibited by 8-methylquinoline derivatives possessing subnanomolar binding and long residence times. Br. J. Pharmacol. 171: 1287-98 [PMID:24670150]

95. Sears RM, Liu RJ, Narayanan NS, Sharf R, Yeckel MF, Laubach M, Aghajanian GK and DiLeone RJ. (2010) Regulation of nucleus accumbens activity by the hypothalamic neuropeptide melanin-concentrating hormone. J. Neurosci. 30: 8263-73 [PMID:20554878]

96. Shearman LP, Camacho RE, Sloan Stribling D, Zhou D, Bednarek MA, Hreniuk DL, Feighner SD, Tan CP, Howard AD and Van der Ploeg LH et al.. (2003) Chronic MCH-1 receptor modulation alters appetite, body weight and adiposity in rats. Eur. J. Pharmacol. 475: 37-47 [PMID:12954357]

97. Shimada M, Tritos NA, Lowell BB, Flier JS and Maratos-Flier E. (1998) Mice lacking melanin-concentrating hormone are hypophagic and lean. Nature 396: 670-4 [PMID:9872314]

98. Shimomura $Y$, Mori M, Sugo $T$, Ishibashi $Y$, Abe M, Kurokawa $T$, Onda $H$, Nishimura $O$, Sumino $Y$ and Fujino M. (1999) Isolation and identification of melanin-concentrating hormone as the endogenous ligand of the SLC-1 receptor. Biochem Biophys Res Commun 261: 622-626 [PMID:10441476]

99. Smith DG, Davis RJ, Rorick-Kehn L, Morin M, Witkin JM, McKinzie DL, Nomikos GG and Gehlert DR. (2006) Melanin-concentrating hormone-1 receptor modulates neuroendocrine, behavioral, and corticolimbic neurochemical stress responses in mice. Neuropsychopharmacology 31: 1135-45 [PMID:16205780] 
100. Suply T, Della Zuana O, Audinot V, Rodriguez M, Beauverger P, Duhault J, Canet E, Galizzi JP, Nahon JL and Levens $\mathrm{N}$ et al.. (2001) SLC-1 receptor mediates effect of melanin-concentrating hormone on feeding behavior in rat: a structure-activity study. J. Pharmacol. Exp. Ther. 299: 137-46 [PMID:11561073]

101. Suzuki T, Kameda M, Ando M, Miyazoe H, Sekino E, Ito S, Masutani K, Kamijo K, Takezawa A and Moriya $M$ et al.. (2009) Discovery of novel diarylketoxime derivatives as selective and orally active melaninconcentrating hormone 1 receptor antagonists. Bioorg. Med. Chem. Lett. 19: 5339-45 [PMID:19683441]

102. Takahashi A, Kosugi T, Kobayashi Y, Yamanome T, Schiöth HB and Kawauchi H. (2007) The melaninconcentrating hormone receptor 2 (MCH-R2) mediates the effect of $\mathrm{MCH}$ to control body color for background adaptation in the barfin flounder. Gen. Comp. Endocrinol. 151: 210-9 [PMID:17324419]

103. Takekawa S, Asami A, Ishihara $Y$, Terauchi J, Kato K, Shimomura Y, Mori M, Murakoshi H, Kato K and Suzuki N et al.. (2002) T-226296: a novel, orally active and selective melanin-concentrating hormone receptor antagonist. Eur. J. Pharmacol. 438: 129-35 [PMID:11909603]

104. Tan CP, Sano H, Iwaasa H, Pan J, Sailer AW, Hreniuk DL, Feighner SD, Palyha OC, Pong SS and Figueroa DJ et al.. (2002) Melanin-concentrating hormone receptor subtypes 1 and 2: species-specific gene expression. Genomics 79: 785-92 [PMID:12036292]

105. Tavares FX, Al-Barazanji KA, Bishop MJ, Britt CS, Carlton DL, Cooper JP, Feldman PL, Garrido DM, Goetz AS and Grizzle MK et al.. (2006) 6-(4-chlorophenyl)-3-substituted-thieno[3,2-d]pyrimidin-4(3H)-onebased melanin-concentrating hormone receptor 1 antagonist. J. Med. Chem. 49: 7108-18 [PMID:17125263]

106. Tsunematsu T, Ueno T, Tabuchi S, Inutsuka A, Tanaka KF, Hasuwa H, Kilduff TS, Terao A and Yamanaka A. (2014) Optogenetic manipulation of activity and temporally controlled cell-specific ablation reveal a role for MCH neurons in sleep/wake regulation. J. Neurosci. 34: 6896-909 [PMID:24828644]

107. Tyhon A, Lakaye B, Adamantidis A and Tirelli E. (2008) Amphetamine- and cocaine-induced conditioned place preference and concomitant psychomotor sensitization in mice with genetically inactivated melaninconcentrating hormone $\mathrm{MCH}(1)$ receptor. Eur. J. Pharmacol. 599: 72-80 [PMID:18848539]

108. Verlaet M, Adamantidis A, Coumans B, Chanas G, Zorzi W, Heinen E, Grisar T and Lakaye B. (2002) Human immune cells express ppMCH mRNA and functional MCHR1 receptor. FEBS Lett. 527: 205-10 [PMID:12220661]

109. Wang S, Behan J, O'Neill K, Weig B, Fried S, Laz T, Bayne M, Gustafson E and Hawes BE. (2001) Identification and pharmacological characterization of a novel human melanin-concentrating hormone receptor, mch-r2. J. Biol. Chem. 276: 34664-70 [PMID:11459838]

110. Willie JT, Sinton CM, Maratos-Flier E and Yanagisawa M. (2008) Abnormal response of melaninconcentrating hormone deficient mice to fasting: hyperactivity and rapid eye movement sleep suppression. Neuroscience 156: 819-29 [PMID:18809470]

111. Witty DR, Bateson J, Hervieu GJ, Al-Barazanji K, Jeffrey P, Hamprecht D, Haynes A, Johnson CN, Muir AI and O'Hanlon PJ et al.. (2006) Discovery of potent and stable conformationally constrained analogues of the MCH R1 antagonist SB-568849. Bioorg. Med. Chem. Lett. 16: 4872-8 [PMID:16839763]

112. Wu M, Dumalska I, Morozova E, van den Pol A and Alreja M. (2009) Melanin-concentrating hormone directly inhibits $\mathrm{GnRH}$ neurons and blocks kisspeptin activation, linking energy balance to reproduction. Proc. Natl. Acad. Sci. U.S.A. 106: 17217-22 [PMID:19805188]

113. Ziogas DC, Gras-Miralles B, Mustafa S, Geiger BM, Najarian RM, Nagel JM, Flier SN, Popov Y, Tseng YH and Kokkotou E. (2013) Anti-melanin-concentrating hormone treatment attenuates chronic experimental colitis and fibrosis. Am. J. Physiol. Gastrointest. Liver Physiol. 304: G876-84 [PMID:23538494] 